\title{
Muhammad, profeternes segl og Daniels Bog
}

\section{Et ekko i Koranen af oldkirkens profetforståelse?}

\section{Cand.theol. Melissa Sayyad Bach og professor, dr.theol. Jesper Høgenhaven}

\begin{abstract}
In the Qur'an Muhammad calls himself "Seal of the Prophets". The metaphor indicates that he sees himself as concluding and completing the line of prophets. This rare and unusual image seems to originate from Dan 9:24, which is strange, since the Book of Daniel or the prophet Daniel is never mentioned in the Qur'an. In this article, we attempt to trace the tradition behind the seal metaphor. This investigation brings us to Tertullian, who calls Christ the "Seal of all Prophets", in a Christological interpretation of Dan 9:24. From here we survey the usage of seal metaphors in the Hebrew Bible, the Septuagint, the Vulgate, and the Book of Revelation. We briefly examine the occurrence of seal metaphors in Manichean tradition, and finally we analyze the reception of Daniel in the Syriac tradition.
\end{abstract}

Key words: Muhammad - Qur'an - Seal - Prophets - Book of Daniel - Tertullian - LXX - Book of Revelation - Mani - Aphrahat - Syriac church.

I Koranen kaldes Muhammad "profeternes segl” (K 33,40). Billedet forekommer kun denne ene gang i Koranen. Segl-metaforen synes at udtrykke to ting: Muhammad er den sidste og største profet i en lang række; og hans budskab bekræfter således de tidligere profeters åbenbaringer. Samtidig er han den, der definitivt afslutter og dermed "lukker" profeternes række. En tilsvarende dobbelthed i forhold til tidligere åbenbaringer møder vi mange gange i Koranen: Guds åbenbaring til Muhammad beskrives som den endegyldige guddommelige meddelelse, der både stadfæster alle tidligere meddelelser og bringer rækken af meddelelser til afslutning. Selve billedet af Muhammad som segl er dog ret påfaldende. Senere islamisk tradition kender en forestilling om, at Muhammad siden sin barndom bærer "profetiens segl” på sin krop som et synligt tegn på sin særlige status og opgave.

Ifølge en tradition hos Ibn Sa'ad (784-845) er det en syrisk kristen munk, der første gang opdager "profetiens segl" på Muhammads ryg under en rejse. Denne fortælling om Muhammads møde med den syriske munk samt den mere overordnede antagelse, at den syriske kirke har været en inspiration for Muhammads åbenbaringer, har 
sendt os på jagt efter at finde en mere håndgribelig forbindelse mellem de forskellige aktører. Den nordafrikanske kirkefader Tertullian (ca. 160-225) bruger betegnelsen "alle profeters segl" om Kristus via en kristologisk tolkning af Dan 9,24. Ifølge flere arabiske, muslimske forfattere brugte også manikæismens grundlægger Mani (ca. 216276) betegnelsen "profeternes segl" om sig selv.

Hverken profeten Daniel eller Daniels Bog forekommer eksplicit noget sted i Koranen, så hvor stammer inspirationen til Muhammads selvbeskrivelse fra? I det følgende vil vi forsøge at give en plausibel forklaring på det tidsmæssige spring mellem Muhammads selvbeskrivelse som profeternes segl og Tertullians kristologiske anvendelse af seglmetaforikken fra Dan 9,24. Vores udgangspunkt er seglmetaforen i Koranen og i islamisk overlevering. Dernæst undersøger vi brugen af seglbilledet hos Tertullian, hvor det første gang kan dokumenteres som en kristologisk betegnelse. Tertullian henter forestillingen om, at Kristus er "profeternes segl” fra Dan 9,24. Daniels Bogs billede af profetiernes "forsegling" har en kompliceret teksthistorie: Seglbilledet findes i den hebraiske tekst og i en del af den græske teksttradition (Theodotion), medens den ældre græske tradition og de øvrige versioner taler om "opfyldelse" og ikke "forsegling" i Dan 9,24. Segl og forsegling bruges metaforisk i en række bibelske sammenhænge. Her har seglbilledet en tilsvarende dobbelt betydning som i Koranen: Seglet bekræfter og afslutter en bestemt meddelelse eller et givet kognitivt indhold.

Vi gennemgår kort referencerne til Mani som profeternes segl for at se om de kan være en forbindelse til Koranens seglbillede. Den tyske koranforsker Hartmut Bobzin har peget på den syriske kirke og specielt kirkefaderen Afrahat (270-345) som en eventuel forbindelse mellem oldkirkens kristologiske brug af seglbilledet og Koranen; og vi forsøger gennem en analyse af Afrahats brug af Daniels Bog at udforske denne mulighed nærmere.

Koranens segl (Sura 33,40)

En enkelt gang betegner Koranen Muhammad som "profeternes segl" (K 33,40): 
Muhammad er ikke fader til nogen af jeres mænd; men han er Guds udsending og profeternes segl. Gud ved alting (K 33:40). ${ }^{1}$

Udsagnet forekommer i en sammenhæng, som tilsyneladende omhandler en familiestrid og understreger Muhammads ret til at ægte sin adoptivsøn Zayds fraskilte hustru. Betegnelsen "profeternes segl" (khätama l-nabiyyina) synes i den konkrete sammenhæng mest af alt at tjene som en fremhævelse af Muhammads betydning og autoritet. Nogen nærmere forklaring eller tolkning af seglmetaforen finder vi ikke i denne passage. ${ }^{2}$ Det er nærliggende at forstå "segl" som et udtryk for, at Muhammad på en gang afslutter og bekræfter rækken af foregående profeter. Seglet sættes på et dokument som en bekræftelse på afsenderens autoritet; og med forseglingen er det tydeliggjort, at dokumentet er "lukket" og afsluttet, og at der ikke længere kan ændres eller redigeres i teksten. ${ }^{3}$

Det er omdiskuteret, præcis hvilken betydning denne understregning af Muhammads særlige profetiske status har i sammenhængen i K 33,40. Det giver mening at se den første del af verset - om, at Muhammad ikke er "fader til nogen af jeres mænd" - som en begrundelse for, at det er tilladt ham at ægte Zayds hustru, da Zayd trods adoption ikke er Muhammads søn og Zayds hustru dermed ikke hans svigerdatter. På en måde kan henvisningen til Muhammad som profeternes segl, altså afslutningen på profeternes række, siges at underbygge denne pointe: Muhammad er ikke (som en biologisk fader til sønner ville være det) ophavsmand til kommende generationer men netop højdepunktet og afslutningen på åbenbaringernes historie. $^{4}$

1. Koranen er her og i det følgende citeret efter: Koranen. Oversat af Ellen Wulff (København: Vandkunsten ${ }^{3} 2013$ ).

2. Jf. Carsten Colpe, "Das Siegel der Propheten", Orientalia Suecania XXXIIIXXXV (1984-1985), 71-83 (71).

3. Til spørgsmålet om mundtlig og skriftlig overlevering i tidlig islam, se Gregor Schoeler, The Oral and the Written in Early Islam (New York: Routledge 2006). Jf. også Johannes Pedersen, Den arabiske bog (København: Fischers Forlag 1946), 10-16.

4. Der er forskellige opfattelser - både i islamisk tradition og blandt moderne forskere - af, hvilken betydning det har, at ingen af Muhammads sønner når at blive voksne. Jf. til diskussionen Uri Rubin, "The Seal of the Prophets and the Finality of Prophecy. On the Interpretation of the Qur'ānic Sūrat al-Ahzāb (33)”, ZDMG 164 (2014), 65-96 (67-71, 76-82). I overleveringen bliver det forhold, at Muhammad ikke efterlader sig sønner, forbundet med hans status som den sidste profet. Rubin argumenterer for, at en vigtig pointe i K 33,40 er, at Muhammad ligesom tidligere profeter, specielt Moses, blev mødt med uberettigede anklager på grund af sine hustruer, men blev frikendt af Gud. Se til Zayd-traditionen David S. Powers, Zayd (Philadelphia: University of Pennsylvania Press 2014). 
Det er således ikke vanskeligt at forstå seglbilledet rent intuitivt $\mathrm{i}$ dets foreliggende sammenhæng i Koranen. Ideen om Muhammad som den afsluttende profet, der fuldender en lang række af forudgående budbringere og dermed indtager en enestående plads, er et tema i flere koraniske sammenhænge:

Jøderne og de kristne siger: "Vi er Guds børn og dem, som Han elsker." Sig: "Hvorfor straffer Han jer da for jeres synder? Nej, I er mennesker blandt dem, som Han har skabt. Han tilgiver, hvem han vil, og straffer, hvem Han vil." Herredømmet over himlene og jorden og alt derimellem tilhører Gud. Hos Ham ender alt.

I Skriftens folk! Vor udsending er kommet til jer for at oplyse jer efter et tidsrum uden udsendinge, så at I ikke skal sige: "Der kom ingen til os med et godt budskab og for at advare!" Nu er der kommet en til jer med et godt budskab og for at advare. Gud er i stand til alt (K 5:18-19).

Flere Koran-passager opererer med rækker af profeter, hvis meddelelse er gået forud for Guds åbenbaring til Muhammad. ${ }^{5}$ Undertiden fremhæver Koranen nogle af de tidligere profeter frem for andre. Således hedder det i Sura 33, at "vi sluttede en pagt med profeterne, med dig, Noah, Abraham, Moses og Jesus, Marias søn! Vi sluttede en stærk pagt med dem" (K 33:7). Andetsteds er det Jesus alene, hvis særlige status understreges:

Nogle af disse udsendinge har vi udmærket frem for andre. Nogle af dem har Gud talt til, og andre har han hævet i rang. Jesus, Marias søn, gav Vi de klare beviser, og Vi styrkede ham med den hellige ånd. Hvis Gud havde villet, havde de, der kom efter ham, ikke bekæmpet hinanden; men de blev uenige. Nogle af dem var troende, mens andre var vantro. Hvis Gud havde villet, havde de ikke bekæmpet hinanden; men Gud gør, hvad han ønsker (K 2:253).

Muhammads profetiske meddelelse - som på en gang er et godt budskab og en advarsel (K 5,19) - omslutter og indoptager de tidligere meddelelser fra Gud, en struktur, der konkret kommer til udtryk gennem indordningen af såvel jøder som kristne i en universel åbenbaringshistorie. De guddommelige meddelelser, som i fortiden blev givet til disse folk, er gyldige men samtidig ophævet i den nye

5. Den nøjagtige rækkefølge kan variere: Vi finder f.eks. rækken Abraham, Ismael, Isak, Jakob, Moses, Jesus i K 2,136, og Abraham, Isak, Jakob, Moses, Aron, Ismael og Idris i K 19,41-57. I Sura 21 har vi Abraham, Lot, Isak, Jakob, Noa, David, Salomo, Job, Ismael, Idris, Dhu l-Kifl, Jonas ("ham med fisken”, dhu l-buni), Zakarias, Johannes og Maria ("hun, som forblev jomfru”) som profetrække. 
oplysning, som Gud har meddelt gennem Muhammad. ${ }^{6}$ Det virker indlysende, at det er denne grundlæggende tankegang, ifølge hvilken Muhammad på en gang fuldender og afslutter profeternes række, som er udtrykt i betegnelsen "profeternes segl".

Carsten Colpe har peget på en uoverensstemmelse imellem brugen af seglmetaforen i K 33,40 og Koranens sprogbrug i øvrigt: Udtrykket "forsegle" er i Koranen generelt negativt konnoteret (Colpe 1984-1986, 72-73). Her betegner verbet "forsegle" (khatama) typisk at "lukke til", "gøre forstokket", og det bruges i forbindelse med udsagn om, at Gud forhærder de vantros hjerter:

Gud har forseglet deres hjerter og hørelse; over deres blik ligger der et slør. De har en vældig straf i vente (K 2,7).

Sig: "Hvad mener I: Hvis Gud fratog jer synet og hørelsen og forseglede jeres hjerte, hvilken anden gud end Gud kunne da give jer det tilbage?"... (K 6,46)

Hvad mener du: Den, der har gjort sit begær til sin gud, og som Gud med velberåd hu har ledt vild, hvis ører og hjerte Han har forseglet, og over hvis øjne Han har lagt et slør, hvem kan retlede ham efter Gud? Vil I ikke lade jer påminde? $(\mathrm{K} 45,23)$

Seglbilledet i K 33,40 virker mao ikke som den gængse brug af metaforikken, som den ellers optræder i Koranens sammenhæng. Denne diskrepans kunne tyde på, at titlen "profeternes segl" i K 33,40 var en allerede foreliggende traditionel formel. Den selvfølgelighed, hvormed billedet indføres i sammenhængen uden nærmere forklaring, kunne pege i samme retning (Colpe 1984-1986, 71-73). Den foreliggende traditionelle formel må Koranen dermed have overtaget andetsteds fra.

6. De gammeltestamentlige fortællinger bliver også sammenfattet til en historie om guddommelig tilgivelse og menneskelig ulydighed, som det sker i Sura 5: "Vi sluttede pagt med Israels børn og sendte udsendinge til dem. Hver gang en udsending bragte dem noget, de ikke brød sig om, beskyldte de nogle af dem for at lyve, og andre slog de ihjel. De regnede med, at der ikke ville være nogen prøvelse. De var blinde og døve. Gud tilgav dem, men igen blev mange af dem blinde og døve. Gud ser, hvad de gør" (K 5:70-71). Denne type tilbageskuende sammenfatninger virker som et ekko af oldkirkelige kristne forfatteres brug af Det Gamle Testamente. 


\section{"Profetiens segl" på Muhammads ryg}

I senere islamisk tradition findes en overlevering, der handler om, at Muhammad fra sin barndom er kendetegnet ved et fysisk kendetegn, som kaldes "profetiens segl" (khätama n-nabut). Ibn Sa'ad (784-845), der i sit hovedværk Kitab al-Tabaqat al-Kabir samler et stort antal overleveringer om Muhammads liv, har en hel stribe beretninger om, hvor dette synlige tegn bliver opdaget og bevidnet af forskellige mennesker. ${ }^{7}$ Den tidligste episode forgår under en rejse, hvor den 12-årige Muhammad opdages af en syrisk munk (Ibn Sa'ad I, 40.10, se nedenfor). ${ }^{8}$ Ibn Sa'ad refererer til tidligere forudsigelser af en profet blandt Ismaels efterkommere, hvor "profetiens segl" er det synlige tegn, som denne profet vil have imellem sine skuldre (I, 40.26). En profeti, der tillægges en kristen, som har læst den i et hidtil uopdaget blad i de kristnes hellige bog, "evangeliet" (al-injil), beskriver profetiens segl mellem Muhammads skuldre sammen med andre fysiske træk: Hverken for høj eller for lav, lys i huden, to hårlokker (II, 75.12). I andre fortællinger kommer tegnet ved en tilfældighed til syne i forbindelse med, at Muhammad udfører underfulde gerninger (I, 42.31).

Ibn Sa'ad kender tilsyneladende også den koraniske tradition om Muhammad som profeternes segl, og tillægger Muhammad det direkte udsagn, at han er "mere end tusind profeters segl" (I, 43.11). I ham er profeterne beseglet (I, 43.10), hvad der uden tvivl vil sige så meget som, at deres række er afsluttet. I en beskrivelse af Muhammads skønhed, som føres tilbage til Ali hedder det, at "profetiens segl var mellem hans skuldre, og han var den sidste af profeterne" (II, 92.5). Her viser det sig, hvordan motivet med det synlige "segl" på Muhammads krop er traditionens konkrete visualisering af Koranens tanke om Muhammad som afslutningen på profeternes række.

7. Ibn Saad, Biographien Muhammeds, seiner Gefährten und der späteren Träger des Islams bis zum Jahre 230 der Flucht. Herausgegeben von Eduard Sachau (Leiden: E.J. Brill 1905).

8. Legenden om munken, der opdager Muhammad, er bevidnet i kristne kilder som en apologetisk fortælling om munken som Muhammads lærer. Jf. Barbara Roggema, The Legend of Sergius Bahira: Eastern Christian Apologetics and Apocalyptic in Response to Islam, The History of Christian-Muslim Relations 9 (Leiden: Brill 2008). I islamisk tradition er det et mønster, at kristne bevidner Muhammads profetstatus. 


\section{Tertullians segl og Daniel 9,24}

Tertullian kalder i skriftet mod jøderne (Adversus Iudaeos, ca. 208 e. Kr.) Kristus for alle profeters segl (signaculum omnium prophetarum). ${ }^{9}$ Det sker i en sammenhæng, hvor Tertullian tolker Dan 9,24 som en profeti om Kristi komme til verden. Daniel-tekstens tale om, at "det højhellige bliver salvet", udlægger Tertullian som et udtryk for salvningen af Kristus, den højhellige, og den besegling af "syn og profeter", som er omtalt i Dan 9,24, forstår Tertullian som et udsagn om forholdet imellem profeti og opfyldelse og som en bekræftelse af, at Kristus er den sidste profet eller afslutningen på profeternes epoke:

Et manifestata est iustitia aeterna et unctus est sanctus sanctorum id est Christus et signata est visio et prophetes et dimissa sunt peccata, - quae per fidem nominis Christi omnibus in eum credentibus tribuuntur. Quid est autem quod dicit signari visum et prophetiam ? Quoniam omnes prophetae nuntiabant de illo, quod esset venturus et pati haberet, igitur quoniam adimpleta est prophetia per adventum eius, propterea signari visionem et prophetiam dicebat, quoniam ipse est signaculum omnium prophetarum adimplens omnia quae retro de eo nuntiaverant.

Og den evige retfærdighed kom til syne og den højhellige, det er Kristus, blev salvet, og synet og profeterne blev beseglet, og synderne blev forladt, hvad der ved troen på Kristi navn bliver tilkendt alle, som tror på ham. Men hvad vil det sige, at syn og profeti bliver beseglet? Eftersom alle profeterne forkyndte om ham, at han skulle komme og at han måtte lide, da profetien således er opfyldt gennem hans komme, derfor sagdes han at besegle syn og profeti, for han er selv alle profeters segl, der opfylder alt, hvad de tidligere havde bebudet om ham (A.J. 8,12). ${ }^{10}$

Tertullian fortsætter med at slå fast, at der efter Kristi komme og efter hans lidelse ikke længere kan være noget syn eller nogen profeti, der bebuder hans komme. Fordi Tertullian således entydigt bestemmer det egentlige profetiske budskab som forjættelse om Kristus, giver det sig selv, at profeti må være noget, der frelseshistorisk hører hjemme i forjættelsens tid, altså tiden indtil Kristus. Denne frelseshistoriske bestemmelse af profetien som noget fortidigt finder Tertullian også

9. Carsten Colpe (1984-1986, 76-78) har vistnok som den første gjort opmærksom på denne brug af seglmetaforen hos Tertullian.

10. Tertullians latinske tekst er her og i det følgende citat gengivet efter: Tertullian, Adversus Iudaeos/Gegen die Juden überstetzt und eingeleitet von Regina Hauses, Fontes Christiani 75 (Turnhout: Brepols Publishers 2007). Oversættelsen er vores egen. 
bekræftet i Kristi udsagn i Matt 11,13 om loven og profeterne, der profeterede indtil Johannes Døberen:

Post enim adventum eius et passionem ipsius iam non visio neque prophetes qui Christum nuntiet venturum. denique si non hoc ita est, exhibeant Iudaei prophetarum post Christum aliqua volumina, angelorum aliquorum visibilia miracula, quae retro patriarchae viderunt usque ad adventum Christi qui iam venit. Ex quo signata est visio et prophetia id est statuta, et merito evangelista: "Lex et prophetae usque ad Iohannem baptizatorem". Baptizato enim Christo id est sanctificante aquas in suo baptismate omnis plenitudo spiritalium retro charismatum in Christo cesserunt signante visiones et prophetias omnes quas adventu suo adimplevit. Unde firmissime dicit adventum eius signare visum et prophetiam.

For efter hans komme og lidelse er der nu ikke længere syn eller profeter, der bebuder den kommende Kristus. Endelig: Hvis det ikke forholder sig sådan, lad jøderne fremvise nogle profetbøger efter Kristus eller nogle synlige undere ved engle, som patriarkerne så dem lige indtil Kristi komme, ham, som nu er kommet. Derefter er syn og profeti forseglet, det vil sige fastsat, også ifølge evangelisten: "Loven og profeterne indtil Johannes Døberen”. For da Kristus var blevet døbt, det vil sige, da han havde helliget vandet ved sin dåb, ophørte hele fylden af tidligere åndelige nådegaver i Kristus, idet han beseglede alle de syner og profetier, som han ved sit komme havde opfyldt. Derfor står det udsagn fast, at hans komme besegler syn og profeti (A.J. 8,12-15)

I sin tolkning af Dan 9,24 veksler Tertullian imellem "syn og profeter" og "syn og profeti" (visiolvisus et prophetia), hhv. "syner og profeter" (visiones et prophetias).

\section{Daniel 9,24 i tekstoverleveringen}

Udgangspunktet for Tertullian er passagen Dan 9,20-27, hvor englen Gabriel forklarer Daniel meningen med Jeremias' Bogs udsagn om, at Jerusalem skal ligge i ruiner i halvfjerds år. Åbenbaringen er et svar på Daniels bøn i Dan 9,4-19. Gabriel meddeler nu Daniel, at den fastsatte frist for folket og den hellige by er på halvfjerds uger, som er den endegyldige termin for de begivenheder, som skal finde sted: 


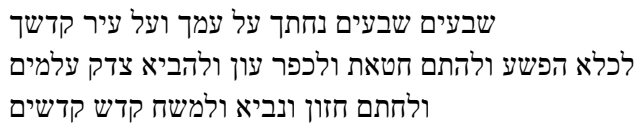

Halvfjerds uger er fastsat for dit folk og for din hellige by, før overtrædelserne bliver tøjlet, synden bragt til ophør og skylden sonet, før den evige retfærdighed kommer, før profeternes syner bliver beseglet, og det højhellige bliver salvet (Dan 9,24).

חתם ("B)esegle") har som objekt "syn og profet" (חזון ונביא). Den danske 1992-oversættelse forstår plausibelt nok det dobbelte objekt som en omskrivning af "profeternes syner". Den hebraiske tekst tillader dog også en forståelse, hvor det dels er "synet", den givne åbenbaring eller de givne åbenbaringer, som besegles, dels "profeten”, der kan forstås som fænomen eller institution eller som hele rækken af tidligere profeter.

Daniels Bog er i den antikke græske bibeltradition overleveret i to skikkelser: 1) LXX-teksten eller den ældre græske tekst, 2) den tekst, der traditionelt betegnes Theodotion. Netop for Daniels Bogs vedkommende er den sidstnævnte tekstform ikke beslægtet med Theodotion-teksten i andre dele af GT, men repræsenterer en selvstændig jødisk oversættelse måske fra 1 . årh. f. Kr. ${ }^{12}$ LXX har en forholdsvis fri omskrivning af Gabriels budskab:

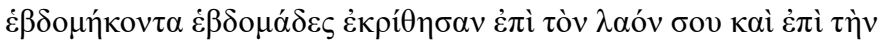

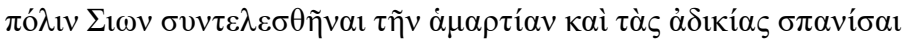

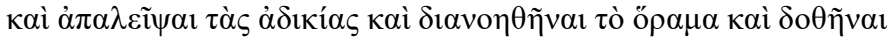

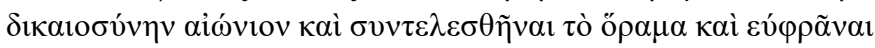

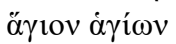

Halvfjerds uger er fastsat for dit folk og for byen Zion, før synden bliver opfyldt og overtrædelserne ophører, og overtrædelserne bliver sonet, og man tænker over synet, og evig retfærdighed bliver givet, og synet bliver opfyldt, og man glæder sig over det højhellige.

11. Verbet חת er dannet af den samme rod som det arabiske ord for "segl" (khätam), der bruges i Koranens segl-vers (K 33:40).

12. Jf. Louis F. Hartmann \& Alexander A. di Lella, The Book of Daniel, The Anchor Bible 23 (Garden City: Doubleday 1978), 82. Til den komplicerede teksthistorie bag de forskellige græske versioner af Daniels Bog se Aleaxander A. di Lella, "The Textual History of Septuagint-Daniel and Theodotion-Daniel”, The Book of Daniel: Composition and Reception, Vol. 2, red. John J. Collins \& Peter W. Flint, Supplements to Vetus Testamentum 83/II (Leiden-Boston-Köln: Brill 2001), 586-607. 
Her er seglbilledet helt forsvundet, idet der ikke længere tales om at "forsegle" men mere alment om at synet ( $\tau$ ò ó $\rho \alpha \mu \alpha)$ bliver "opfyldt"

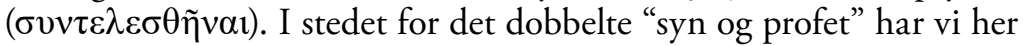
det overordnede begreb "synet" ( $\tau$ ò ő $\rho \alpha \mu \alpha$ ). I Vulgata finder vi en tilsvarende omskrivning, hvor "besegle" er blevet til det mere almene "opfylde", og "profeter" blevet til "profeti" (et impleatur visio et prophetia). Peshitta har ligeledes omskrevet "besegle" til "opfylde" men beholdt den hebraiske teksts "syn og profet", idet her dog er tale om "profeter" i flertal (

I den såkaldte Theodotion-tekst skinner den massoretiske teksts billede tydeligere igennem:

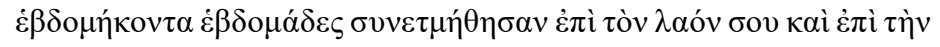

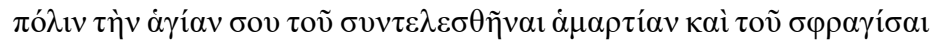

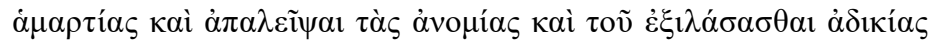

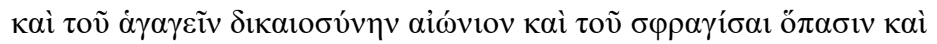

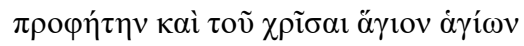

Halvferds uger er fastsat for dit folk og for din hellige by, før synden bliver opfyldt, og synderne bliver beseglet, og overtrædelserne bliver sonet, og uretfærdigheden sonet, og evig retfærdighed kommer, og syn og profet bliver beseglet, og det højhellige salvet.

Tertullian går i Adversus Iudaeos tydeligvis ud fra en Danieltekst, der taler om, at "syn og profeter" bliver beseglet (signata est visiolvisus et prophetes). Han forudsætter dermed en latinsk bibeltekst, der afspejler Theodotion-tekstens udgave af Dan 9,24. Det er på ingen måde overraskende, siden det var Theodotion-teksten, der blev den almindeligt brugte i kristen tradition; den ældre græske Daniel-tekst har kun overlevet $\mathrm{i}$ nogle få håndskrifter og $\mathrm{i}$ en langt senere syrisk over-

13. I den sidste del af Dan 9,24 har Peshitta en anden vigtig variant i forhold til den hebraiske tekst: I stedet for ולמשח קדש קדשים ("og det højhellige bliver salvet") har Peshitta wlmšyh' qdwš qwdšyn ("og til den salvede er det højhellige"). Et enkelt håndskrift har wmšyh uden præposition, så meningen bliver: "og den salvede er det/ den højhellige”. Peshittas læsemåde kan under alle omstændigheder siges at lægge en kristologisk tolkning af det sidste udsagn nærmere. I Dan 9,26, hvor den massoretiske tekst taler om, at "en salvet" bliver "fjernet" (יכרת, egentlig "skåret af"), taler Peshitta mere entydigt om, at den salvede bliver "dræbt" (ntqtl). Disse nuanceforskelle har givet anledning til en diskussion om, hvorvidt Peshitta er oversat af jødekristne, eller der er tale om tilfældigheder. Jf. Richard A. Taylor, The Peshitta of Daniel, Monographs of the Peshitta Institute Leiden 7 (Leiden-New York.Köln: Brill 1994), 9. 
sættelse. ${ }^{14}$ Når Tertullian kan skifte imellem at tale om profeter og profetier, er det en mulighed, at han kender mere end en tekstform. Det virker, som om "profeterne" som den konkrete række af åbenbaringsmodtagere og "profetierne", det budskab, som er indeholdt $\mathrm{i}$ de gammeltestamentlige profetiske skrifter, for Tertullian glider ubesværet over i hinanden. Det hænger efter alt at dømme sammen med, at han i forvejen betragter profeti som et fortidigt, skriftligt fikseret fænomen. ${ }^{15}$

\section{Seglmetaforik i Bibelen}

I Daniels Bog forekommer seglbilledet to gange i bogens afsluttende kapitel: Her befaler englen Daniel at "holde ordene skjult og forsegle bogen til endetiden" (Dan 12,4; MT: וחתם הספר עד עת קץ; LXX og

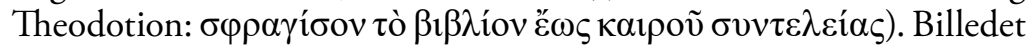
gentages i Dan 12,9, hvor Daniel får at vide, at ordene "holdes skjult

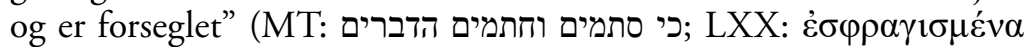

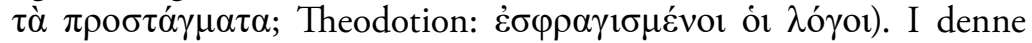
kontekst synes forseglingen af den indsigt, som er meddelt Daniel, at stå for en hemmeligholdelse af det meddelte: Det skal forblive utilgængeligt indtil den fastsatte termin. Dette hemmeligheds-motiv går igen i Dan 8,26, hvor seeren ligeledes får besked på at holde synet skjult (MT: סתם החזון), fordi det gælder fremtiden (MT: כילים (רימים (רבים). Her har Theodotion-teksten gengivet verbet ("skjule") med

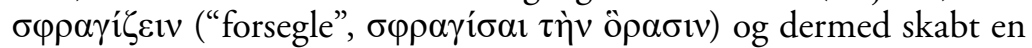
endnu tydeligere forbindelse til Dan 9,24; 12,4.9.

Der er en væsentlig nuanceforskel imellem brugen af seglbilledet $\mathrm{i}$ Dan 9,24 og i Dan 12,4.9. Hvor det i slutkapitlet er hemmeligholdelsen af budskabet indtil den fastsatte tid, der er i centrum, er det i Dan 9,24 snarere stadfæstelsen af de tidligere syner og profetier, det drejer sig om. Her er fokus på det tidspunkt ude i fremtiden, hvor trængslerne for Guds folk skal bringes til ophør; og til den tid vil syner og profetier finde deres bekræftelse.

14. LXX-teksten er bevaret i papyrus 967 (2.-3. årh.), manuskript 88 (9.-11. årh.) og i Paulus af Tellas Syrohexapla-oversættelse (615-617 e.Kr., vigtigste håndskrift. Codex Ambrosianus fra 9. årh.). Theodotion-teksten synes at have fortrængt den ældre græske oversættelse engang i løbet af det 2.-3. århundrede. Jf. di Lella (2001), 586-588.

15. Til Tertullians brug af Dan 9 mere overodnet se Geofrrey D. Dunn, "Tertulian and Daniel 9:24-27. A Patristic Interpretation of a Prophetic Time-Frame”, ZAC 6 (2002), 352-367. 


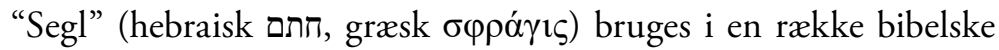
sammenhænge i sin gængse, dagligdags betydning. ${ }^{16}$ Som metafor betegner det "forseglede" noget, som holdes lukket eller er utilgængeligt som i Højs 4,12. I Es 8,16 bruges seglmetaforen om en lukning/ forsegling af et budskab: "Jeg binder til for budskabet, jeg forsegler belæringen hos mine disciple" (MT: צור תעודה חתום תורה בלמדי). ${ }^{17}$ Motivet er her som i Dan 12,4.9 hemmeligholdelsen eller utilgængeligheden af det meddelte budskab indtil en fastsat termin.

LXX har en anden udgave af Es 8,16: "Da skal de, som forsegler sig

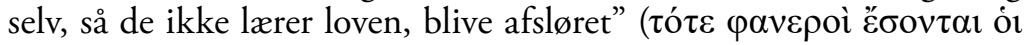

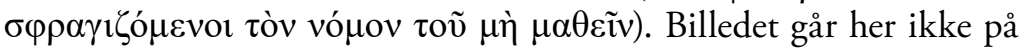
profetens disciple, som bevarer et budskab i deres indre. I stedet er det de ulydige, der har "forseglet" sig selv, så de ikke tager lovens ord til sig, der er i centrum. ${ }^{18}$ Seglmetaforikken som udtryk for det utilgængelige budskab tages op igen i Es 29,11-12, hvor det om det forstokkede folk hedder, at ethvert syn (חזות הכל) bliver som ord i en forseglet bog (כדברי הספר החתום), som hverken den læsekyndige eller den ikke-læsekyndige kan tyde. LXX har en anden forestilling: Her er

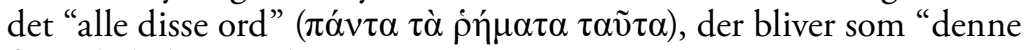

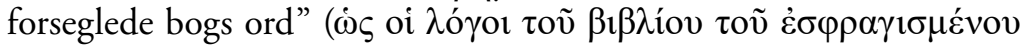
$\tau$ 七ó $\tau$ ), hvad der synes at lægge en større vægt på forestillingen om det profetiske budskab som en afsluttet skriftligt fikseret størrelse.

I GT ser vi således en dobbelt brug af seglmetaforikken: Som illustreret ovenfor, betyder forseglingen af et budskab eller et kognitivt indhold, at dette bliver utilgængeligt eller skjult (Es 8,16; 29,11-12; Dan 12,4.9). I andre sammenhænge ligger vægten på, at budskabet/ indholdet bekræftes (Dan 9,24). Den flertydighed, der kendetegner seglmetaforikken i GT, minder dermed om flertydigheden i Koranens seglmetaforik.

En markant videreførelse af seglmetaforikken finder vi i nytestamentlig sammenhæng i Johannes' Åbenbaring. Billedet er koncentreret om to elementer, der begge optræder i begyndelsen af den første visionsrække (Åb 4-7): Her har vi på den ene side den lukkede

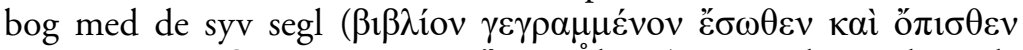

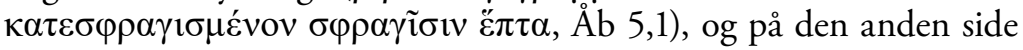

16. 1 Kong 21,8; Neh 10,1.2; Ester 3,12; 8,8.10; Jer 32, 10.11.14.44. I Dan 6,18 forsegler kong Dareios stenen, der lukker løvekulen.

17. Det er uklart om det er profeten eller Jahve der taler i 1. person i Es 8,16 og om det er profetens eller Jahves disciple der tales om.

18. I LXXs udgave bliver begyndelsen af Es 8,16 dermed en direkte fortsættelse af domsudsagnet i Es 8,15. Det følgende udsagn i Es 8,17, der drejer sig om at vente håbefuldt på Jahve, er i LXX tydeligt afgrænset fra Es 8,16: Det nye afsnit begynder

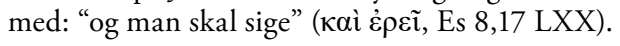


lammet/Kristus-figuren, der præsenteres som den eneste, der er værdig til at bryde bogens segl (Åb 5,9). I den efterfølgende sekvens bryder lammet de første seks segl et efter et, idet hvert brudt segl udløser nye katastrofer (Åb 6).Den forseglede bog, der er beskrevet på begge sider, kunne ligne en forening af elementer fra forskellige gammeltestamentlige tekster: Den dobbelte skrift stammer fra Ezek 2,10, mens segl-elementet virker som et ekko af Es 29,11-12 og Dan 12,4.9. Johannes' Åbenbaring indeholder en lang række eksplicitte og implicitte referencer til Daniels Bog, som sammen med Ezekiels Bog hører til skriftets vigtigste kilder. Særligt rummer visionen af den himmelske trone og lammet i Åb 4-5 ekkoer af scenen i Dan 7, der også beskriver Guds trone, hvor der er tale om en universel dom, og hvor bøger spiller en central rolle.

I Daniels Bog står seglmetaforen i Dan 9,24 i en anden sammenhæng end trone- og domsscenen i Dan 7; og der er ikke umiddelbart nogen forbindelse imellem bøger og segl som i Johannes’ Åbenbaring. På den anden side kan det ikke udelukkes, at den intensive brug af seglbilledet i Johannes' Åbenbaring kan være påvirket af Dan 9,24 eller ligefrem udformet med denne tekst som udgangspunkt. Den forseglede bog i Åbenbaringen ser ud til at indeholde den guddommeligt fastsatte dom over verden og kunne dermed også have forbindelse til tidligere tiders profetier. Det er en afgørende pointe, at det er lammet/Kristus, som er værdig til at bryde bogens segl. Først med Kristi komme vil de i bogen forudsagte domsbegivenheder blive virkeliggjort.

Åbenbaringen gør således kreativt brug af den gammeltestamentlige seglmetaforik; og i denne forbindelse er der meget, der tyder på, at Dan 9,24 har spillet en central rolle som inspiration. ${ }^{19}$

\section{Mani som profeternes segl}

Vi har set, at Tertullian er den ældste forfatter, der bruger udtrykket "profeternes segl" i denne sammenhæng om Kristus. Som illustreret henter han sit grundlag fra Dan 9,24 og den bibelske seglmetaforik. Mellem Tertullian og Koranens seglbillede er der et kronologisk "hul” på ca. 400 år. Nogle forskere har peget, at Dan 9,24 kunne

19. Det er et tydeligt udtryk for Åbenbaringens uafhængige omgang med traditionen, at vi i bogens slutningskapitel finder en befaling til seeren, der vender motivet med den forseglede profeti i Daniels Bog på hovedet. I Åb 22,10 får seeren udtrykkelig besked på ikke at forsegle profetiens ord i denne bog ( $\mu$ ì $\sigma \varphi \rho \alpha \gamma i \varsigma$ nฺ

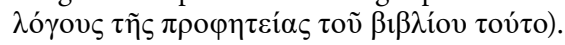


have spillet en rolle i manikæisk tradition (Jf. Colpe 1984-1986, 7477)..$^{20}$

Ifølge den muslimske arabiske forfatter al-Birūnī (d. ca. 1050) hævdede Mani, grundlæggeren af manikæsimen, om sig selv, at han var "parakleten", som Messias havde forudsagt, og "profeternes segl" (khätama l-nabiyyina). ${ }^{21}$ Det er et omdiskuteret spørgsmål, om selvbetegnelsen, som også nævnes hos andre muslimske forfattere, afspejler selvopfattelsen hos Mani, eller den snarere er et udtryk for islamisk polemik mod manikæismen. Det kunne sagtens være en pointe hos muslimske forfattere, at manikæernes grundlæggerfigur på formastelig vis havde tilkendt sig selv en ære, som rettelig tilkommer Muhammad. Det er dog også muligt, at manikæerne på et tidspunkt, hvor de befandt sig under islamisk overherredømme, kunne være begyndt at overtage Koranens seglbillede og at insistere på, at det i virkeligheden var Mani og ikke Muhammad, der var "profeternes segl" (Stroumsa 1986, 63).

Udtrykket "profeternes segl" findes i enkelt passage i en tekst af manikæisk herkomst. Det drejer sig om en uygurisk oversættelse af en forskrift for syndsbekendelse, Xuāstvānīft, der taler om de "fire lyssegl" i hjertet. ${ }^{22}$ Teksten kan muligvis bygge på et ældre forlæg, måske fra det 6. århundrede eller tidligere (Stroumsa 1986, 68). Det fjerde af de fire "lyssegl" er visdommen, "profeternes segl". Lysseglene i hjertet hos de "hørende" manikæere skal i sammenhængen beskytte mod synd og vranglære; og som det fjerde og sidste af disse lyssegl er visdommen en stadfæstelse af den lære, som profeterne repræsenterer. I denne sammenhæng synes profeterne at være en anden betegnelse for de "udvalgte", dvs. kernen i den manikæiske kirke. Seglmetaforen har således en anden betydning i denne tekst end i Koranen: Her er der ikke tale om en profet, der afslutter rækken af tidligere profeter men snarere om den manikæiske kirke selv, der betragtes som profeter. Og

20. Jf. også Carsten Colpe, "Jesus und die Besiegelung der Prophetie", Berliner Theologische Zeitschrift 4 (1987), 2-18 (14-15); Gedaliahu G. Stroumsa, "'Seal of the Prophets'. The Nature of a Manichaean Metaphor", Jerusalem Studies in Arabic and Islam 7 (1986), 61-74; Stroumsa, The Making of the Abrahamic Religions in Late Antiquity (Oxford: Oxford University Press 2015), 87-99, Róbert Simon, "Mānī und Muhammad", JSAI 21 (1997), 118-140.

21. Citeret efter Stroumsa 1986, 61-74.

22. Den relevante passage er gengivet i Stroumsa 1986, 68. Oversættelsen er hentet fra Jes P. Asmussen, Xuāstvānīft. Studies in Manichaeism, Acta Theologica Danica 7 (København: Munksgaard 1965), 196 ("In Äzura täyri, in the God of the sun and Moon, in the powerful God and the prophets we have put our trust, we have relied on them (and) have become Auditors. Four Light Seals have we sealed in our hearts: Firstly Love, The seal of Äzura täyri, secondly Faith, the seal of the God of the Sun and Moon, thirdly the Fear (of God), the seal of the Fivefold God, (and) fourthly Wisdom, the seal of the prophets"). 
seglet betegner ikke i denne kontekst, at noget afsluttes eller lukkes, men at den visdom, som er indeholdt i den manikæiske kirkes tradition, bliver bekræftet (Jf. Stroumsa 1986, 69-70). På denne baggrund er der for mange uvisheder forbundet med antagelsen af, at Mani eller manikæismen har gjort brug af seglmetaforikken i Daniels Bog.

\section{Muhammad, Daniel, Afrahat og den syriske kirke}

Så vidt vi ved, er Hartmut Bobzin (2009) den første, der inddrager Afrahat som et muligt bindeled mellem Tertullian og Muhammad, dog uden at undersøge denne forbindelse nærmere. ${ }^{23}$ Bobzin henter denne tanke fra en monografi af den svenske forsker Tor Andrae fra 1936. ${ }^{24}$ I dette værk peger Andrae på den syriske kristendom som afgørende faktor for formgivningen af Muhammads tidlige religiøse åbenbaringer. Dette illustrerer Andrae ved en fortælling, han har fra Ibn Sa'ad, og som vi kort omtalte tidligere: I en alder af tolv år var Muhammad med sin onkel Abu Talib på en karavanerejse til Syrien. På rejsen bliver Muhammad opsøgt af en syrisk munk, fordi munken ser en sky på himmelen, der skygger for Muhammad, samt et træ, der bøjer sine grene, så han bliver beskyttet mod ørkensolen. Ifølge fortællingen bliver den syriske munk overbevist om, at der er noget særligt ved den 12-årige Muhammad, og undersøger derfor drengen grundigt. Herefter forklarer munken for Abu Talib, at Muhammad bærer profetiens segl mellem sine skuldre (Andrae 1938, 37-38).

Fortællingen om Muhammads møde med den syriske munk underbygger på et generelt plan antagelsen af, at den syriske kristendom har inspireret Muhammad og Koranen. Det har ikke været muligt at finde en direkte forbindelse mellem den syriske kirke og seglmetaforikken; men i kirkefaderen Afrahats værk XXIII Demonstrationer finder vi en gentagen anvendelse af Dan 9,24 samt et stort kendskab til Daniels Bog generelt. Således fremstår Daniels Bog som en afgørende referenceramme i Afrahats værk. Inden vi ser nærmere på nogle eksempler på Afrahats anvendelse af Daniels Bog, er det nødvendigt at skitsere et billede af den syriske kirke på Afrahats tid og kirkefaderen selv.

23. Hartmut Bobzin, “"The Seal of the Prophets": Towards an understanding of Muhammad's Prophethood". The Qur'an in Context. Historical and Literary Investigations into the Qur'anic Milieu, red. Angelika Neuwirth \& Nicolai Sinai m.fl. (Leiden: Brill 2009).

24. Jf. Tor Andrae, Mohammed: The Man and His Faith (New York: Dover Publications, Inc 2000), 37-38. 


\section{Afrahat og den syriske kirke}

Afrahat (270-345 e. Kr.), også kendt som “den persiske vismand", er en af de første kirkefædre inden for den syriske kirke, og som navnet antyder, stammede han fra Persien. Tidligere i forskningen var der en bred enighed om, at Afrahat var biskop af Mar Mattai. ${ }^{25}$ Men denne tese er i nyere tid blevet stærkt betvivlet, idet man mener, at der ikke fandtes et klostervæsen på dette tidlige tidspunkt. ${ }^{26}$ Området Mar Mattai lå på den østlige side af Tigris, som tilhørte det persiske rige, og er i dag bedst kendt som Mosul.

Afrahats forfatterskab, XXIII Demonstrationer, giver et unikt og værdifuldt indblik i den tidlige syrisk-semitiske kristendom i det 4 . årh. ${ }^{27}$ I værket viser Afrahat et omfattende og kyndigt kendskab til bibelske tekster, hvorudfra han behandler forskellige teologiske problematikker. Den kristendom, som Afrahat er en repræsentant for, kan siges at være den mindst helleniserede form, upåvirket af den græsk-romerske strømning og tankegang. ${ }^{28}$ Værket er forfattet på elegant klassisk syrisk, og rækkefølgen på de 23 kapitaler har akrostisk form, hvilket vil sige, at rækkefølgen i det syriske alfabet er fulgt. ${ }^{29}$

Første del af værket blev til i årene 336-337, og de sidste 13 Demonstrationer er skrevet i årene 344-345 under forfølgelsen af de kristne, som var forårsaget af det persiske rige (Morrison 2004, 56). Værket behandler presserende problematikker - eksempelvis XXI. Demonstration - Om Forfolgelse, som tolker forfølgelsen i lyset af tolv gammeltestamentlige helte og Jesus. Forfølgelsen var grundet i de kristnes modstand mod at betale skat til Shapur II, som opkrævede skat for sine krige mod det kristne Rom (Neusner 1971, 4). Derudover afspejler værket et anstrengt forhold til jøderne, som tilsyneladende nød en større frihed end de kristne. Jødedommen var på denne tid rodfæstet og blomstrede i det persiske rige (mange af de kristne var forhenværende jøder). Det var nødvendigt at tegne en klar linje mellem jødedom og kristendom. ${ }^{30}$

25. Jacob Neusner, Aphrahat and Judiasm: Christian-Jewish Argument in Fourth -century Iran, Studia Post Biblica (Leiden: E. J. Brill 1971), 282.

26. Adam Lehto, The Demonstrations of Aphrahat, the Persian Sage (Piscataway: Gorgias Press LLC 2010), 5.

27. Craig E. Morrison. "The reception of the Book of Daniel in Aphrahat's Fifth Demonstration, 'On Wars'”. Hugoye 7, (2004) 55-82 (55).

28. Jeff W Childers, "We Must Seek the Truth, Theological Scholarship in the Early Syriac Tradition”. Restoration Quarterly 49 (2007) 193-216 (195).

29. De første 22 kapitaler følger det syriske alfabet, men det 23. kapitel (XXIII. Demonstration) er markeret ved alef som startbogstav på alfabetrækken.

30. Clark M. Williamson. "The 'Adversus-judaeos' Tradition in Christian Theology”. Encounter 39 (1978), 273-296 (288). 
I det følgende vil vi i hovedtræk belyse Afrahats anvendelse af Daniels Bog først i $V$. Demonstration - Om Krig og dernæst i XXI. Demonstration - Om Forfolgelse.

\section{Demonstration}

I 25 mindre afsnit behandler V. Demonstration - Om Krig den politisk-religiøse situation for den syriske kirke omkring 337 e. Kr. Konstantin den store havde overtaget magten i Romerriget, og idet kristendommen blev til statsreligion, anså de persiske herskere de kristne i deres rige som en potentiel trussel. Denne frygt voksede sig større, idet Konstantin erklærer sig selv som den guddommeligt indsatte beskytter, der skulle værne om alle kristne verden rundt (Morrison 2004, 55-56). Afrahat håber på, at den romerske kejser vil komme de kristne i det persiske rige til undsætning, men han er ikke klar over, at mens han skriver $V$. Demonstration, dør Konstantin. Langt fra hvad Afrahat havde af forhåbninger, sætter det persiske rige året efter (338) en systematisk forfølgelse af de kristne i gang.

Afrahat forsikrer sine læsere, at tiden og historien er under Guds kontrol, både den gode og ikke mindst trængslens tid. I Daniels Bog finder Afrahat et trøstende og håbefuldt budskab til den samtidige kirke. Især i Dan 2; 7; 8 ser Afrahat en historisk forståelse, som skal realiseres i hans samtid. Daniels kryptiske og gådefulde univers bliver en oplagt scene, hvor den politisk-religiøse situation på Afrahats tid kan udspilles (Morrison 2004, 55).

Et gennemgående tema er, at Gud griber ind i historien; de onde og undertrykkerne skal ydmyges, og en belønning venter de gode. Denne pointe beskriver Afrahat ved at pege på to gammeltestamentlige skikkelsers skæbne, Nebukadnezar og Sankerib, hvor hovmod og arrogance bliver deres undergang. Synet om vædderen og gedebukken (Dan 8) anvender Afrahat til at sende en tilsløret advarsel til den samtidige hersker af perserriget Shapur II. Her sammenligner Afrahat vædderen med den persiske konge Darius I og gedebukken med Alexander den store. Med denne allegoriske sammenligning ønsker Afrahat at vise, at den syriske kirkes skæbne er i Guds hænder, idet dens forfølger, vædderen Shapur II's skæbne er forudsagt, og han vil blive skaffet af vejen. 


\section{Demonstration}

Den systematiske forfølgelse af de kristne, der begyndte i 338, har sat sine spor i XXI. Demonstration - Om Forfolgelse, som består af 23 mindre afsnit og formodes at være skrevet omkring 345. Derfor må Afrahat nu forklare og forsvare forfølgelsen i en større sammenhæng. Dette gør han ved at forklare forfølgelsens tematik i lyset af gammeltestamentlige figurer, som sammenholdes med Jesus. Den bibelske fortolkningsramme kan siges at være oplagt, idet Afrahat hovedsageligt forsvarer forfølgelsens tilstedeværelse over for de jødiske anklager. Apologien kommer til udtryk via en eksegetisk debat med en jødisk vismand. Den overordnede dagsorden i XXI. Demonstration er at vise, at selvom de kristne på Afrahats tid er forfulgte, betyder det ikke, at Gud har forladt dem. Derimod har de kristne forfølgelsen tilfælles med gammeltestamentlige helte. Afrahat fremhæver således tolv gammeltestamentlige heltefigurer som forgængere for og billeder på den forfølgelse, som Jesus senere kommer til at stå over for.

Gennem en typologisk sammenligning af Jesus med de tolv gammeltestamentlige heltefigurer fremhæver Afrahat, hvorledes de forfulgte modtager en stor belønning, mens forfølgerne modtager straf og dømmes. ${ }^{31}$ Ved en nogenlunde kronologisk skildring af den pågældende GT-helt fremhæver Afrahat, hvorledes heltens liv og forfølgelse er et billede på, hvordan Jesus blev forfulgt. Derefter skildrer Afrahat, hvorledes forfølgelsen af helten ender i belønning, og hvorledes Jesu forfølgelse ender i belønning til frelse for hele verden.

\section{Afrahats anvendelse af Dan 9,24 i XXI. Demonstration}

De typologiske sammenligninger begynder i afsnit 9: "Joseph who was persecuted was a type of persecuted Jesus" (Gwynn 1898, 662). ${ }^{32}$ Længere nede i samme afsnit sammenholder Afrahat Josefs evne til at se syner og drømme med Jesus som den, der opfylder visioner og profetier. At betragte Jesus som den, der opfylder visioner og profetier, synes at rumme et stærkt ekko af Dan 9,24. Afrahat anvender verbet هلد (ml') og ikke (slm), som er det verbum, der optræder i Peshitta. Men disse to verber kan siges at fungere som synonymverber

31. De tolv helte er Josef, Moses, Josva, Jefta, David, Elias, Elisa, Hizkija, Josias, Daniel, Hananja og Mordokaj.

32. John Gwynn, Selections of Translated into English from The Hymns and Homilies of Ephraim The Syrian, and from the Demonstrations of Aphrahat The Persian Sage (Dublin: University of Dublin 1898), 664. 
med en kommensurabel betydning at fuldende eller opfylde. ${ }^{33}$ Objekterne syn og visioner er ordret de samme som i Dan 9,24.

To yderligere anvendelser af Dan 9,24 forekommer i afsnit 18, hvor beretningen om Daniel skildres i lyset af Jesus. Ligesom i tidligere afsnit indledes dette afsnit med: "Daniel was also persecuted as Jesus was persecuted" (Gwynn 1898, 666). Hvor Daniel forklarer og udlægger Nebukadnezars drømme, opfylder Jesus synet og profeterne ( til Dan 9,24, som det optræder ordret i Peshitta. Hvor Daniels belønning for at udlægge Belshassars drøm bliver at være den tredjemægtigste i riget, modtager Jesus al autoritet i himmelen og på jorden som belønning fra Faderen. Ved Daniel blev der afsløret hemmeligheder og oplevet undere, hvor der ved Jesus blev åbenbaret hemmeligheder

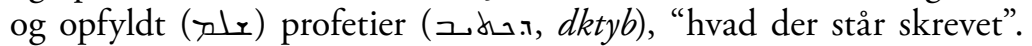
Her optræder igen det samme verbum at opfylde fra Dan 9,24.

Daniels Bog forekommer således som en afgørende teologisk ramme, som Afrahat fortolkningsmæssigt benytter i $V$. Demonstration. Derudover anvender Afrahat også Dan 9,24 i XXI. Demonstration til at vise, hvorledes Jesus bliver opfyldelsen af det, der er forudsagt, skrevet og ikke mindst set i Det Gamle Testamente.

\section{Konklusion}

Jagten på Muhammad som profeternes segl sendte os på en spændende tidsrejse via Tertullian og hans brug af Det Gamle Testamente, til seglmetaforikken i den masoretiske tekst, LXX, Vulgata og seglbilledet i Johannes' Åbenbaring. Endvidere bragte rejsen os omkring Mani og den manikæiske tradition og endelig til den syriske kirke og Afrahat.

Den bemærkelsesværdige opdagelse og fællesnævner for alle disse stationer var deres reception og anvendelse af Daniels Bog. Her forsøgte vi at demonstrere hvorledes Daniels Bog blev flittigt læst og udlagt i den tidlige kristne kirke. Man tolkede bogens profetiske budskab på den måde, at Kristus er opfyldelsen af alle profetier. Med Kristus er profetiernes tid forbi, idet alle profetier er opfyldt og overgået. Når Koranen indoptager og sammenfatter alle tidligere guddommelige åbenbaringer og gør dem til forløbere for Guds åbenbaring til Muhammad, virker det som et ekko af de oldkirkelige kristne

33. Som nævnt tidligere bruger Peshitta ikke udtrykket "besegle" men "opfylde" i Dan 9,24. 
forfatteres brug af Det Gamle Testamente. Således overtager Koranen den kristne traditions måde at tolke de ældre profetiske tekster på med fuldendelsen eller opfyldelsen som det nødvendige udgangspunkt. Samtidig foretager Koranen en fuldstændig omvending af den kristne traditions læsning ved at sætte Muhammad ind på Kristi plads. Det er dette, som markant udtrykkes gennem overtagelsen af betegnelsen "profeternes segl", der overføres på Muhammad. 